\title{
Karakterisasi Lima Isolat Cendawan Endofit Tanaman Padi Sebagai Agen Antagonis Pyricularia Oryzae

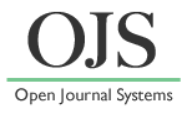

\author{
Ika Nurfatimah", Tunjung Pamekas, Hartal \\ Program Studi Proteksi Tanaman, Fakultas Pertanian, Universitas Bengkulu, Bengkulu \\ *Email: ikanurfatimah16@gmail.com
}

DOI: https://doi.org/10.33369/pendipa.4.3.1-6

\begin{abstract}
Endophytic fungi are microorganisms that live in plant tissues or plant organs, such as seeds, leaves, flowers, stems and roots which are able to induce plant resistance to diseases. Local isolate of endophytic fungi is expected more effective to control diseases. Blast disease, that caused by Pyricularia oryzae, is a limited factor on rice paddy production. This study aim was to characterize dan select endophytic fungi isolates isolated from rice paddy as antagonistic agents to control P. oryzae. The research methods were survey rice paddy in the field, isolation and characterization of endophytic fungi isolates, isolation and characterization of $P$. oryzae, and testing the mechanism of antagonism of endophytic fungi isolates and $P$. oryzae in vitro by dual culture test. The results showed that there were five endophytic fungi isolated from rice paddy, that were Aspergillus candidus, Gliocladium sp, Trichoderma harzianum, Penicillium $s p$, and Nigrospora sp. The eight isolates of endophytic fungi were isolated from various sites having different micro environment. Endophytic fungi isolated from rice paddy at the district of Central Bengkulu demonstrated highest inhibition percentage, which was $85.60 \%$ with competition for space, nutrition and oxygen, antibiosis, and hyperparasitism.
\end{abstract}

Keywords: Bengkulu; Endophytic fungi; in vitro; rice paddy.

\begin{abstract}
ABSTRAK
Cendawan endofit merupakan mikroorganisme yang berada dalam jaringan tanaman atau organ tanaman, seperti biji, daun, bunga, batang dan akar yang mampu menginduksi ketahanan tanaman terhadap penyakit. Cendawan endofit isolat lokal diharapkan memiliki efektivitas kerja yang lebih baik. Penyakit blas pada tanaman padi yang disebabkan oleh Pyricularia oryzae merupakan salah satu faktor pembatas produksi tanaman padi. Penelitian ini bertujuan untuk karakterisasi dan seleksi isolat cendawan endofit dari tanaman padi sebagai agen antagonis dalam pengendalian $P$. oryzae. Metode penelitian meliputi : pengambilan sampel tanaman padi di lapangan, isolasi dan karakterisasi isolat cendawan endofit, isolasi dan karakterisasi $P$. oryzae dari tanaman padi sakit, dan pengujian mekanisme antagonisme isolat cendawan endofit dan $P$. oryzae secara in vitro dengan metode biakan ganda. Dari hasil penelitian diperoleh lima isolat cendawan endofit dari batang dan daun tanaman padi sehat. Kelima isolat cendawan endofit tersebut berasal dari lokasi yang memiliki karakterisasi lingkungan yang berbeda-beda. Lima isolat cendawan endofit tersebut adalah Aspergillus candidus, Gliocladium sp, Trichoderma harzianum, Penicillium sp, dan Nigrospora sp. Isolat cendawan endofit tanaman padi asal Bengkulu Tengah memiliki daya penghambatan tertinggi, yakni $85,60 \%$ dengan mekanisme penghambatan berupa kompetisi ruang, nutrisi dan oksigen, antibiosis, dan hiperparasitme.
\end{abstract}

Kata kunci: Bengkulu; Cendawan endofit; in vitro; tanaman padi.

\section{PENDAHULUAN}

Padi (Oryza sativa L.) merupakan salah satu jenis tanaman pangan yang mempunyai nilai ekonomi tinggi (Saragih, 2001). Berdasarkan data Badan Pusat Statistik (2018), produktivitas padi di Indonesia pada tahun 2018 mengalami peningkatan $0,52 \mathrm{Ku} / \mathrm{Ha}$ yaitu dari tahun 2017 sebesar 51,65 Ku/Ha menjadi 51,92 $\mathrm{Ku} / \mathrm{Ha}$. Produksi padi pada tahun 2017 sebesar 81,148 ton menjadi 83,037 ton pada tahun 2018. Disisi 
lain produktivitas padi di Provinsi Bengkulu mengalami peningkatan sebesar $2,96 \mathrm{Ku} / \mathrm{Ha}$, pada tahun 2017 produksinya menurun dari 731,169 ton menjadi 699,531 ton. Menurut Kasijadi et al. (2007), rendahnya produksi tanaman padi ini terjadi karena ketidakefisienan penggunaan faktor produksi, iklim, degradasi lahan akibat penggunaan pestisida berlebihan, rendahnya kualitas benih yang digunakan, kesuburan tanah, serta serangan oleh organisme pengganggu tanaman (OPT).

Penyakit blas adalah penyakit utama yang dapat menurunkan kualitas dan kuantitas produksi padi. Penyakit ini menyerang pada awal pertumbuhan tanaman fase vegetatif sampai generatif dan patogen ini mampu menyebar melalui udara (air borne) sehingga sangat sulit untuk dikendalikan bahkan dapat menyebabkan gagal panen. Oleh karena itu, penelitian ini perlu dilakukan untuk mendapatkan jenis mikroorganisme cendawan endofit yang berpotensi sebagai agen antagonis Pyricularia oryzae.

Menurut Utami et al. (2005), faktor produktivitas pertanian terutama pada bibit padi menurun akibat adanya serangan serangga, tungau, burung, cendawan, dan bakteri. Salah satu cendawan patogen padi yaitu Pyricularia oryzae yang mampu menurunkan produksi padi sebanyak 90\%. Menurut Wang et al. (2014), penyakit blas yang disebabkan oleh cendawan Pyricularia oryzae Cav. [sinonim Magnaporthe oryzae (Hebert) Barr] merupakan salah satu penyakit penting pada tanaman padi di seluruh dunia. Di Indonesia, penyakit blas sudah menyebar di hampir semua sentra produksi padi (Sudir dkk., 2014).

Cendawan patogen Pyricularia oryzae mampu menyerang tanaman padi pada berbagai stadia pertumbuhan dari benih sampai fase pertumbuhan malai (generatif). Pada tanaman stadium vegetatif biasanya patogen menginfeksi bagian daun disebut blas daun (leaf blast). Pada stadium generatif selain menginfeksi daun juga menginfeksi leher malai disebut blas leher (neck blast). Infeksi patogen juga dapat terjadi pada bagian buku tanaman padi yang menyebabkan batang patah dan kematian yang menyeluruh pada batang atas dari buku yang terinfeksi. Kerugian hasil akibat penyakit blas sangat bervariasi tergantung kepada varietas yang ditanam, lokasi, musim, dan teknik budidaya yang menyebabkan nilai ekonomi padi baik secara kualitas maupun kuantitas menjadi menurun. Pada stadium vegetatif dan stadium generatif dapat menyebabkan kegagalan panen hingga 100\% (Sobrizal et al., 2007).

Menurut (Sugandi dkk., 2010), keanekaragaman hayati adalah berbagai jenis makhluk hidup yang ada di muka bumi ini, maupun yang ada di daratan, dan terdiri dari hewan, tumbuhan, dan mikroorganisme, serta ekosistem yang telah dibentuknya. Keanekaragaman mikroorganisme sangat penting untuk dikaji lebih dalam, salah satunya yaitu keanekaragaman cendawan endofit pada daun dan batang tanaman padi.

Cendawan endofit adalah mikroorganisme yang berada dalam jaringan tanaman atau organ tanaman seperti benih, daun, bunga, batang dan akar. Cendawan endofit memiliki kemampuan menghasilkan beberapa senyawa yang dapat berfungsi sebagai anti bakteri, anti cendawan, hormon pemacu pertumbuhan, dan insektisida (Strobel, 2004; Noverita et al, 2009). Cendawan endofit sangat potensial dikembangkan sebagai agen pengendalian hayati. Penggunaan cendawan endofit yang di isolasi dari tanaman padi diharapkan dapat lebih efektif untuk menekan perkembangan cendawan patogen padi. Dengan demikian belum ada yang meneliti akan pentingnya karakterisasi lima isolat cendawan endofit tanaman padi sebagai agen antagonis Pyricularia oryzae, oleh karena itu penelitian ini perlu diteliti lebih lanjut.

Penelitian ini bertujuan untuk mendapatkan jenis mikroorganisme cendawan endofit yang berpotensi sebagai agen antagonis Pyricularia oryzae.

\section{METODE PENELITIAN}

Tempat dan Waktu. Penelitian ini telah dilaksanakan dari bulan Oktober 2018 sampai Januari 2019 di Laboratorium Proteksi Tanaman, Fakultas Pertanian, Universitas Bengkulu.

Alat dan Bahan. Alat-alat yang digunakan dalam penelitian ini adalah cawan petri, gunting, erlenmeyer, gelas piala, cork borer, gelas objek, jarum ent, mikroskop, plastik bening, penggaris atau meteran, gelas ukur, pipet tetes, pisau, termometer tanah dan udara, hygrometer, ph 
meter (soil tester), dan ATK. Bahan-bahan yang digunakan dalam penelitian ini adalah sampel tanaman padi sehat, sampel tanaman padi bergejala penyakit blas, PDA (Potato Dextro Agar), kapas, etanol 70\%, $\mathrm{FeCl} 3$ 1\%, $\mathrm{NaOCl} 3 \%$, alkohol, kertas saring, dan aquades.

Rancangan Penelitian. Rancangan penelitian yang digunakan yaitu : Survei lokasi tanaman padi dilapangan tepatnya di desa Pekik Nyaring, Kabupaten Bengkulu Selatan.

\section{Tahapan Penelitian.}

\section{Isolasi Cendawan Endofit}

Isolasi cendawan endofit dengan cara mengambil sampel tanaman padi yang sehat, kemudian dibawa ke laboratorium untuk dilakukan isolasi. Bagian yang akan di isolasi yaitu bagian daun dan batang tanaman padi dengan menggunakan metode Rodriques (1994) yang dimodifikasi. Tahapan awal sterilisasi dimulai dengan mencuci batang dan daun padi dengan air mengalir, ditiriskan, lalu dipotong kecil-kecil dengan ukuran $(1 \mathrm{~cm} \quad \mathrm{x} \quad 1 \mathrm{~cm})$. Kemudian sterilisasi bagian permukaan secara bertahap dengan merendam sampel tanaman (batang dan daun) selama 60 detik, dalam etanol $70 \%$ selama 30 detik dan $\mathrm{NaOCl} 3 \%$ selama 60 detik, lalu dibilas sebanyak 4 kali dengan akuades steril dan dikeringkan diatas kertas saring steril, selanjutnya ditumbuhkan dalam media PDA dan diinkubasi selama \pm 5 hari.

\section{Isolasi Pyricularia oryzae}

Isolasi cendawan Pyricularia oryzae padi dilakukan menggunakan metode monokonidia (Agrios, 1988; Bonman et al., 1986). Sampel daun tanaman padi bergejala blas dipotong kecil $( \pm 1 \mathrm{~cm}$ ) lalu direndam $\mathrm{FeCl} 31 \%$ selama satu menit. Potongan daun bergejala tersebut kemudian direndam dalam air steril selama satu menit untuk membilas lalu ditiriskan. Setelah itu 4 potongan sampel disusun pada cawan petri yang telah berisi media PDA lalu diinkubasi pada suhu 37C selama 5-7 hari.

\section{Mekanisme Antagonisme}

Mekanisme antagonisme dilakukan dengan cara mengambil masing-masing biakan murni yaitu : biakan murni cendawan endofit dan biakan murni Pyricularia oryzae dengan menggunakan cork borer berdiameter $7 \mathrm{~mm}$, kemudian diinokulasikan ke media yang berisi PDA secara berhadapan dengan jarak $30 \mathrm{~mm}$.

\section{HASIL DAN PEMBAHASAN}

\section{Karakterisasi Lima Isolat Cendawan}

Endofit Tanaman padi Sebagai Agen Antagonis Pyricularia oryzae

\section{Cendawan Pyricularia oryzae}

Cendawan Pyricularia oryzae secara makroskopis memiliki koloni yang melingkar dan menyebar ke segala arah. Pada awal pertumbuhan di medium PDA koloni berwarna keabu-abuan, kemudian semakin bertambahnya umur inkubasi warna koloni berubah menjadi hitam. Pola pertumbuhan berkoloni dan memiliki bentuk koloni bulat dengan permukaan melingkar (Gambar $1 \mathrm{~A})$.

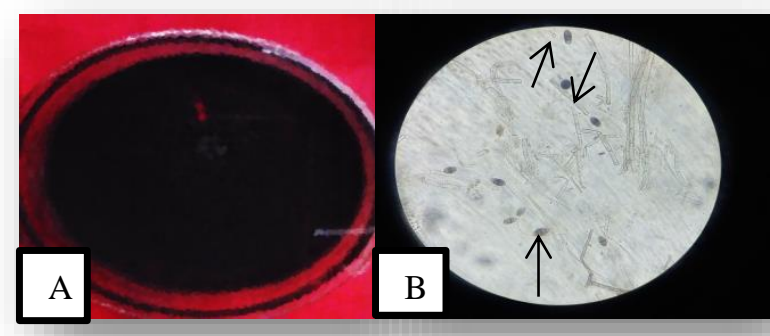

Gambar 1. (A) Koloni Pyricularia oryzae (B) Mikroskopis Pyricularia oryzae = (1) Hifa Pyricularia oryzae, (2) Makrokonidia Pyricularia oryzae, (3) Mikrokonidia Pyricularia oryzae

Dari pengamatan cendawan Pyricularia oryzae secara mikroskopik dapat dilihat bahwa hifa cendawan Pyricularia oryzae bersekat (Gambar 1B1). Makrokonodia berbentuk lonjong dan memiliki sekat 1 sampai 2 (Gambar 1B2). Mikrokonodia bersel satu yang berbentuk bulat telur yang merupakan ciri khas cendawan Pyricularia oryzae (Gambar 1B3).

\section{Karakterisasi Lima Cendawan Endofit}

Berdasarkan ciri-ciri yang ada pada (Gambar 2), maka selanjutnya setiap isolat diidentifikasi berdasarkan buku identifikasi Barnett (1960) dan (Domsch dkk.,1980). Hasil identifikasii cendawan endofit berdasarkan buku identifikasi cendawan oleh Barnett (1960) dan (Domsch dkk.,1980) menunjukkan lima isolat cendawan endofit yang berasal dari Kabupaten Bengkulu 
Tengah di Provinsi Bengkulu yang dikarakterisasi berdasarkan morfologinya menunjukkan perkembangan warna koloni yang berbeda.

Karakter lima isolat cendawan endofit secara mikroskopis yakni bentuk konidiofor, fialid dan konidia disajikan pada (Gambar 2), sebagai berikut:
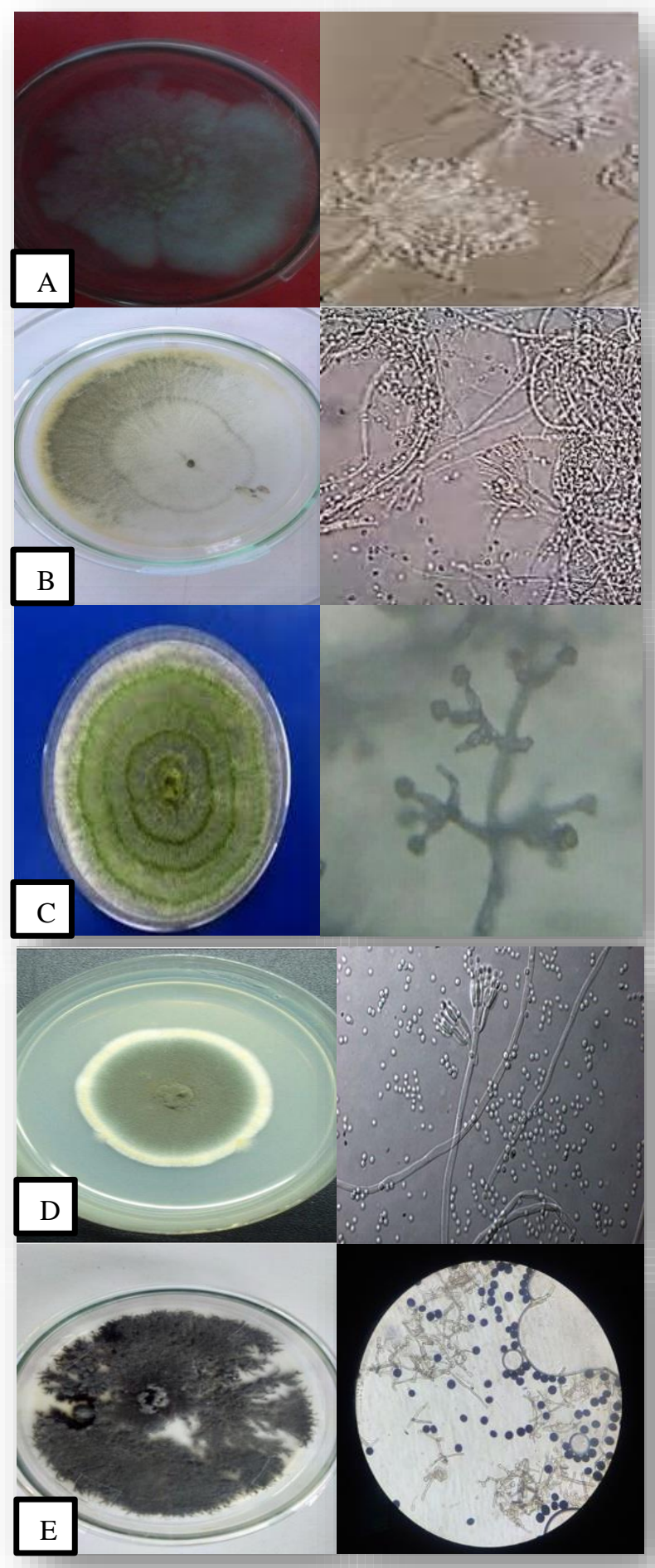

https://ejournal.unib.ac.id/index.php/pendipa
Gambar 2. Koloni, konidiofor, fialid dan konidia isolat cendawan endofit (A) Isolat CE1 Aspergillus candidus. (B) Isolat CE2 Gliocladium sp., (C) Isolat CE3 Trichoderma harzianum, (D) Isolat CE4 Penicillium sp., (E) Isolat CE5 Nigrospora sp. (Sumber: Data primer).

Hasil identifikasi menunjukkan bahwa, isolat kelima cendawan endofit berbedabeda spesiesnya. Spesies Aspergillus candidus menunjukkan bentuk koloni berwarna putih agak kuning. Spesies Gliocladium sp. Bentuk koloni berwarna hijau muda. Spesies Trichoderma harzianum bentuk koloni berwarna hijau muda. Spesies Penicillium sp. bentuk koloni berwarna putih keabu-abuan. Spesies Nigrospora sp. bentuk koloni berwarna hitam. Pada media PDA diameter koloni CE1 sampai CE5 mencapai $8-9 \mathrm{~cm}$ dalam waktu 6 hari setelah inkubasi. Bentuk hifa bersekat, bentuk konidiofor tegak dan bercabang, fialid pendek ataupun panjang serta tebal dan konidia berbentuk oval.

\section{Mekanisme Antagonisme}

Mekanisme antagonisme merupakan cara kerja antagonis di dalam mengendalikan patogen tanaman. Interaksi antara antagonis dengan patogen dalam satu media dapat terjadi berupa kompetisi memperoleh ruang, nutrisi dan oksigen, antibiosis, serta lisis dan parasitisme. Pengamatan mekanisme antagonisme dilakukan pada hari pertama dan kedua selama pengamatan belum terjadi mekanisme antagonisme antar kedua cendawan.

Tabel 1. Mekanisme antagonis Cendawan endofit terhadap Pyricularia oryzae.

\begin{tabular}{cccc}
\hline Kompetisi & & \\
Isolat & $\begin{array}{c}\text { ruang, } \\
\text { nutrisi, } \\
\text { dan } \\
\text { oksigen }\end{array}$ & Antibiosis & $\begin{array}{c}\text { Lisis dan } \\
\text { paratisme }\end{array}$ \\
\hline CE1 & + & + & - \\
CE2 & + & + & - \\
CE3 & + & + & - \\
CE4 & + & + & -
\end{tabular}




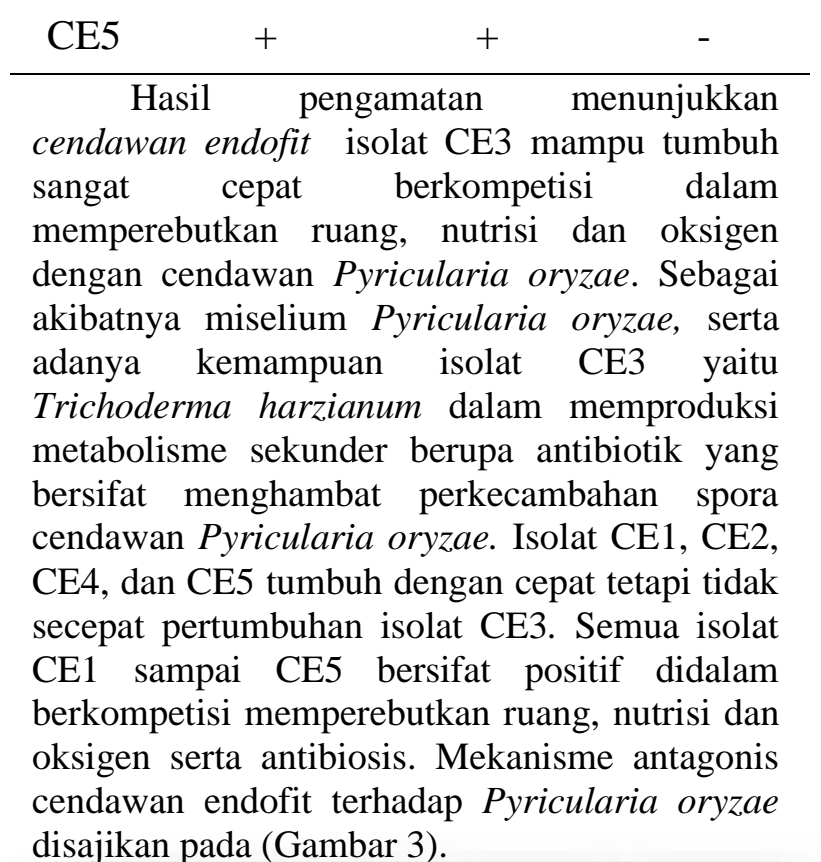

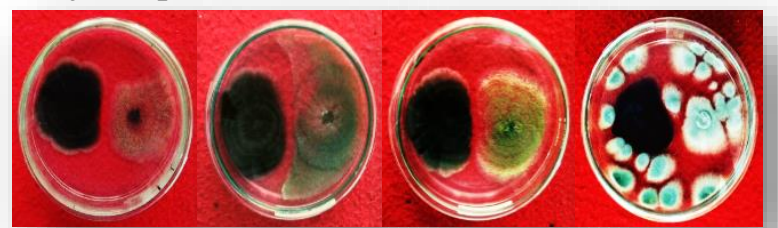

Gambar 3. (A) Kompetisi ruang, nutrisi, dan oksigen tumbuh antara Trichoderma ( $\mathrm{T}$ ) dan F.oxsyporum (F), (B) Antibiosis Trichoderma, (C) Lisis dan parasitisme

Pada penelitian ini didapat data lingkungan asal sampel tanaman padi di Pekik Nyaring Kabupaten Bengkulu Tengah yaitu : dari semua perlakuan memiliki rerata $\mathrm{PH}$ tanah, suhu tanah, kelembaban tanah, kelembaban udara, suhu udara, dan ketinggian masing-masing adalah $5,9,35,6^{\circ} \mathrm{C}, 30 \%, 69,3 \%, 33,3^{\circ} \mathrm{C}$, dan 30 mdpl.

\section{KESIMPULAN}

Dari hasil penelitian diperoleh 5 spesies cendawan endofit yaitu : Aspergillus candidus, Gliocladium sp., Trichoderma harzianum, Penicillium sp., Nigrospora sp.

Isolat yang paling baik uji antagonis nya yaitu pada isolat CE3 Trichoderma harzianum.

\section{UCAPAN TERIMA KASIH}

Saya mengucapkan terima kasih kepada Ibu Dr. Ir. Tunjung Pamekas, M.Sc selaku dosen pembimbing utama yang telah membimbing dengan penuh kesabaran dalam penulisan dan mensuport dalam skripsi ini.

Kepada bapak Ir. Hartal, MP yang telah menjadi dosen pembimbing pendamping saya yang telah sabar dalam membimbing penulisan skripsi saya.

Terima kasih kepada segenap para dosendosen Proteksi Tanaman, Fakultas Pertanian, Universitas Bengkulu yang telah mensuport saya selama menjalani masa skripsi.

Kepada mbak Yani dan pak Zul terima kasih juga telah banyak membantu dalam penelitian saya.

Terima kasih juga kepada adik-adik Proteksi Tanaman yang telah membantu dalam penyelesaian skripsi ini serta mas Candra Wahyudi yang selalu memberi suport dalam menyelesaikan skripsi ini.

\section{DAFTAR PUSTAKA}

Agrios, N.G. 1988. Plant Pathology. Academic Press, University of Florida, USA. p. 198235.

Badan Pusat Statistik (BPS). 2018. Produktivitas Padi di Indonesia 20142018. http://www.bps.go.id/site/pilihdata. Diakses 19 November 2019.

Barnett, H.L. 1960. Illustrated Genera of Imferfect Fungi. Departement of plant pathology, bacteriology, and entomology, west virginia university, Morgantown, West Virginia: 241.

Bonman, J.M., T.I Vergel De Dios, and M.M. Khin. 1986. Physiologic specialization of P. oryzae in the Philippines. Plant Dis. 70:767-769.

Domsch, K.H., Gams W and Anderson TH. 1980. Compendium of Soil Fungi. London: Academics press.

Kasijadi; Ali; Yusran; Wahyunindyawati \& S Balai. 2007. Integrasi Berbasis Padi Ternak.

http://www.jatim.litbang.deptan.go.id.

Diakses 14 Agustus 2019. 
Noverita, Fitria D, Sinaga E. 2009. Isolation and antibacterial activity assay of fungal endophyte of leaves and Rhizome Zingiber ottensii. (in Indonesia). Jurnal Farmasi Indonesia: 4: 171 -176.

Sobrizal, Santoso, Anggiani, and Suwarno. 2007. Rice blast disease in Indonesia. p. 71-80. In Yoshimichi Fukuta, Casiana M. Vera Crus and N. Kabayashi (Ed.). A Differential System for Blast Resistance for Stable Rice Production Environment. JIRCAS Working report No. 53. Tsukuba, Japan.

Saragih, B. 2001. Pengaruh Pemupukan N, P, $K$ Pada Pertumbuhan Dan Hasil Padi (Oryza sativa L.) Kepras. Malang: Universitas Brawijaya.

Strobel GA. 2004. Natural Products from Endophyticmicroorganism. Journal of Natural Products. 67: 257-268.

Sudir, A Nasution, Santoso, dan B Nuryanto. 2014. Penyakit blas Pyricularia grisea padatanaman padi dan strategi pengendaliannya Iptek Tanaman Pangan. 9(2): 85-96.
Sugandi, Y., B.A. Qirana., dan M.R.A. Firmansyah. 2010. Arti Penting Keanekaragaman Hayati Bagi Kelangsungan Kehidupan Di Bumi. (Online). Diunduh dari http://kakgilang.multiply.com/journal/. Diakses 20 Agustus 2019.

Utami DW, Moeljopawiro S, Aswidinnoor H, Setiawan A, Hanarida I. 2005. Gen pengendali sifat ketahanan penyakit blas (Pyricularia grisea Sacc.) pada spesies padi liar Oryza rufipogon Griff. dan padi budidaya IR64. J Agro Biogen. 1(1) : 1-6.

Wang, X, S Lee, J Wang, J Ma, T Bianco, and Y Jia. 2014. Current advances on genetic resistance to rice blast disease. Chapter 7 in the management of rice blast disease. Int. J.Agric. Env. Biotech. 5(3):247-251. 